\title{
Effect of lung-protective ventilation with lower tidal volumes on clinical outcomes among patients undergoing surgery: a meta-analysis of randomized controlled trials
}

\author{
Wan-Jie Gu MSc, Fei Wang MD PhD, Jing-Chen Liu MD PhD
}

\begin{abstract}
Background: In anesthetized patients undergoing surgery, the role of lung-protective ventilation with lower tidal volumes is unclear. We performed a meta-analysis of randomized controlled trials (RCTs) to evaluate the effect of this ventilation strategy on postoperative outcomes.
\end{abstract}

Methods: We searched electronic databases from inception through September 2014. We included RCTs that compared protective ventilation with lower tidal volumes and conventional ventilation with higher tidal volumes in anesthetized adults undergoing surgery. We pooled outcomes using a random-effects model. The primary outcome measures were lung injury and pulmonary infection.

Results: We included 19 trials $(n=1348)$. Compared with patients in the control group, those who received lung-protective ventilation had a decreased risk of lung injury (risk ratio [RR] 0.36, 95\% confidence interval [CI] 0.17 to $0.78 ; P^{2}=0 \%$ ) and pulmonary infection (RR $0.46,95 \% \mathrm{Cl} 0.26$ to $0.83 ; R^{2}=8 \%$ ), and higher levels of arterial partial pressure of carbon dioxide (standardized mean difference 0.47 $95 \% \mathrm{Cl} 0.18$ to $\left.0.75 ; R^{2}=65 \%\right)$. No significant differences were observed between the patient groups in atelectasis, mortality, length of hospital stay, length of stay in the intensive care unit or the ratio of arterial partial pressure of oxygen to fraction of inspired oxygen.

Interpretation: Anesthetized patients who received ventilation with lower tidal volumes during surgery had a lower risk of lung injury and pulmonary infection than those given conventional ventilation with higher tidal volumes. Implementation of a lung-protective ventilation strategy with lower tidal volumes may lower the incidence of these outcomes.
$\mathrm{E}$ stimates suggest that more than 230 million patients undergo major surgical procedures worldwide each year. ${ }^{1}$ Postoperative pulmonary complications, including lung injury, pneumonia and atelectasis, are common and a major cause of morbidity and death. ${ }^{2-5}$ Thus, prevention of these complications has become a high priority of perioperative care.

Mechanical ventilation is mandatory in patients undergoing surgical procedures during general anesthesia. Conventional mechanical ventilation with tidal volumes of 10 to $15 \mathrm{~mL} / \mathrm{kg}$ has been advocated to prevent hypoxemia and atelectasis in anesthetized patients undergoing surgery. ${ }^{6}$ However, unequivocal evidence from experimental and clinical studies suggests that mechanical ventilation, especially the use of high tidal volumes, may cause or aggravate lung injury. ${ }^{7-9}$ Mechanical ventilation using high tidal volumes can result in overdistention of alveoli that mainly causes ventilator-associated lung injury. ${ }^{10}$

Lung-protective ventilation refers to the use of low tidal volumes and moderate to high levels of positive end-expiratory pressure, with or without a recruitment manoeuvre. ${ }^{11}$ Lung-protective ventilation has been found to reduce morbidity and mortality among patients with acute lung injury and acute respiratory distress syndrome. ${ }^{11,12}$ However, in anesthetized patients without the syndrome, the role of lung-protective ventilation remains unclear. Two previous meta-analyses addressing similar research questions have been published, ${ }^{13,14}$ but the inclusion of observational studies compromised the reliability of the results. Recently, randomized controlled trials (RCTs) on the topic have reported conflicting results. We performed a meta-analysis of RCTs to evaluate the effect of lung-protective ventilation with lower tidal volumes on clinical outcomes in patients undergoing surgery.
Competing interests: None declared.

This article has been peer reviewed.

Correspondence to: Jing-Chen Liu, jingchenliu1964@sina.cn

CMAJ 2015. DOI:10.1503 /cmaj.141005 


\section{Methods}

We conducted this study according to the methods of the Cochrane Handbook for Systematic Reviews of Interventions. ${ }^{15}$ The findings are reported according to the Preferred Reporting Items for Systematic Reviews and MetaAnalyses (PRISMA) statement. ${ }^{16}$ There was no formal protocol for the meta-analysis.

\section{Literature search}

We searched PubMed, Embase and the Cochrane Central Register of Controlled Trials from inception through July 2014 to identify relevant RCTs. Electronic searches were performed with the use of exploded Medical Subject Heading $(\mathrm{MeSH})$ terms and corresponding key words. No language restriction was applied. Details of the search strategy are shown in Appendix 1 (available at www.cmaj.ca/lookup/suppl/doi:10.1503 /cmaj.141005/-/DC1). The last search was run on Sept. 12, 2014. We also manually checked the bibliographies of previous reviews and of included studies to identify other potentially eligible trials.

\section{Study selection}

Two of us (W.-J.G. and J.-C.L.) independently conducted the initial search, deleted duplicate records, screened the titles and abstracts for rele-

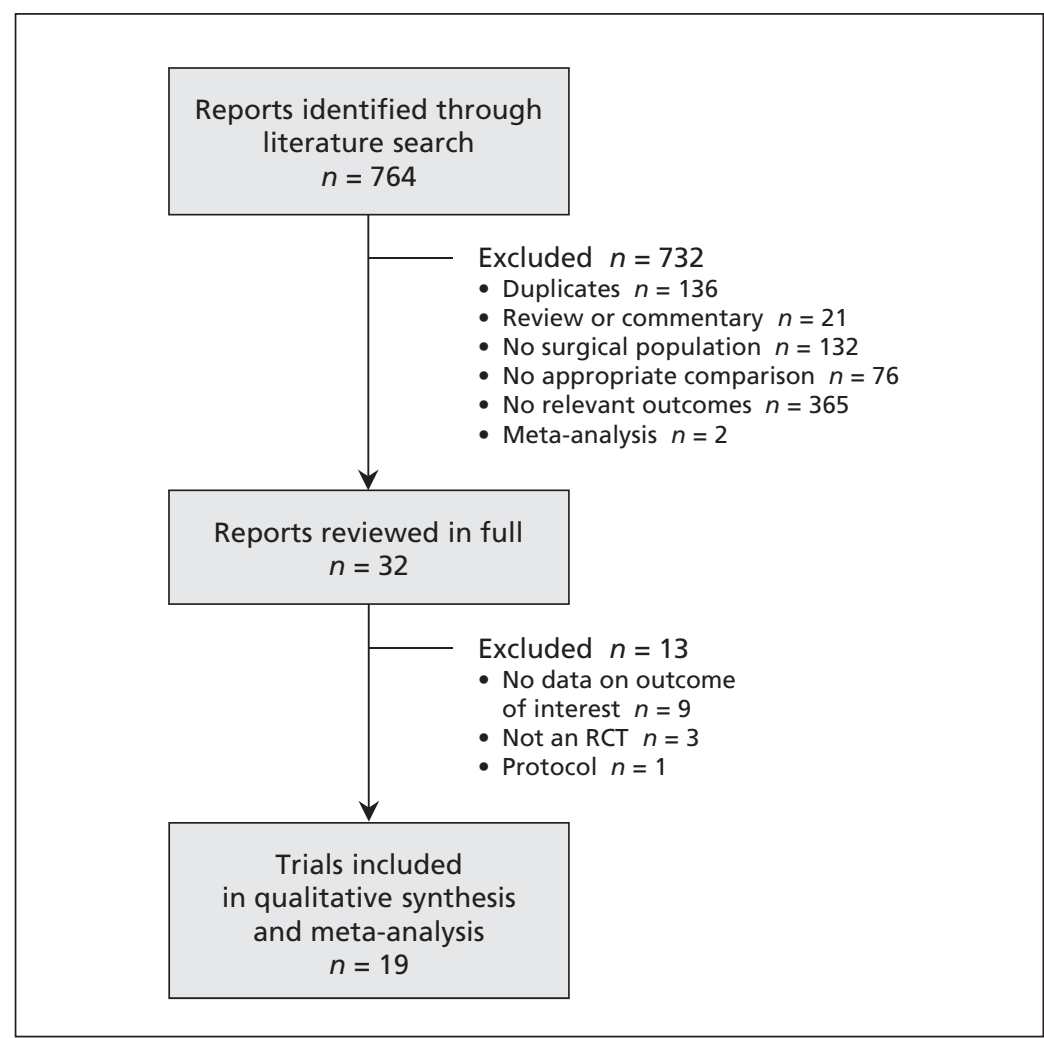

Figure 1: Selection of randomized controlled trials (RCTs) for the meta-analysis. vance and identified records as included, excluded or requiring further assessment. We included published RCTs that met the following 4 criteria: the study population comprised anesthetized adults undergoing any surgical procedure who did not have acute respiratory distress syndrome at the onset of mechanical ventilation; the intervention group received lung-protective ventilation with lower tidal volumes $(5-8 \mathrm{~mL} / \mathrm{kg})$; the comparison group received conventional ventilation with higher tidal volumes $(8-12 \mathrm{~mL} / \mathrm{kg})$; and the trial reported on one or more the following outcomes: lung injury, pulmonary infection, atelectasis, mortality, length of hospital stay, length of intensive care unit (ICU) stay, ratio of arterial partial pressure of oxygen to fraction of inspired oxygen $\left(\mathrm{PaO}_{2} / \mathrm{FiO}_{2}\right)$, or arterial partial pressure of carbon dioxide $\left(\mathrm{PaCO}_{2}\right)$ level. We excluded trials involving patients who were in the ICU before enrolment. Agreement regarding study selection and inclusion was assessed with use of the Cohen kappa statistic.

\section{Data extraction and quality assessment}

The 2 of us involved in selecting the studies also abstracted data (W.-J.G.) and independently confirmed the extracted data (J.-C.L.). The following information was obtained from each study: first author, year of publication, number of patients, demographic characteristics, surgical procedure, tidal volumes, use of positive endexpiratory pressure, use of recruitment manoeuvre in lung-protective and conventional ventilation groups, ventilatory settings and reported outcomes. When duplicate reports of the same study were found, data from the most complete dataset were extracted for analysis. Disagreements were resolved through consensus.

The primary outcome measures were lung injury and pulmonary infection (as defined in the trials). Secondary outcome measures included atelectasis (as defined in the trials), mortality (any death during follow-up), length of hospital stay (time from hospital admission to hospital discharge or death), length of ICU stay (time from ICU admission to ICU discharge or death), $\mathrm{PaO}_{2} / \mathrm{FiO}_{2}$ ratio and $\mathrm{PaCO}_{2}$ level.

The 2 of us who selected the RCTs assessed them independently for risk of bias using the Cochrane risk-of-bias tool. ${ }^{17}$ We assigned a value of low, unclear or high risk of bias to the following domains: random sequence generation, allocation concealment, blinding of participants and personnel, blinding of outcome assessment, incomplete outcome data, selective reporting and other bias. Disagreements were resolved by consensus. We also evaluated the quality of evidence for the outcome measures using the Grading of Recommen- 
Table 1: Characteristics of randomized controlled trials included in the meta-analysis

\begin{tabular}{|c|c|c|c|c|c|c|c|c|c|}
\hline \multirow[b]{2}{*}{ Study } & \multirow[b]{2}{*}{$\begin{array}{l}\text { No. of } \\
\text { patients }\end{array}$} & \multirow[b]{2}{*}{$\begin{array}{l}\text { Surgical } \\
\text { procedure }\end{array}$} & \multicolumn{3}{|c|}{ Lung-protective ventilation } & \multicolumn{3}{|c|}{ Conventional ventilation } & \multirow[b]{2}{*}{ Outcomes } \\
\hline & & & $\begin{array}{l}\text { Tidal } \\
\text { volume, } \\
\mathrm{mL} / \mathrm{kg}\end{array}$ & $\begin{array}{l}\text { PEEP, } \\
\mathrm{cm} \mathrm{H}_{2} \mathrm{O}\end{array}$ & $\begin{array}{l}\text { Recruitment } \\
\text { manoeuvre }\end{array}$ & $\begin{array}{l}\text { Tidal } \\
\text { volume, } \\
\mathrm{mL} / \mathrm{kg}\end{array}$ & $\begin{array}{l}\text { PEEP, } \\
\mathrm{Cm} \mathrm{H}_{2} \mathrm{O}\end{array}$ & $\begin{array}{l}\text { Recruitment } \\
\text { manoeuvre }\end{array}$ & \\
\hline $\begin{array}{l}\text { Chaney } \\
\text { et al., } 2000^{20}\end{array}$ & 25 & CABG & 6 & 5 & No & 12 & 5 & No & $\begin{array}{l}\text { Mortality, length of } \\
\text { hospital stay, } \mathrm{PaCO}_{2} \text { level }\end{array}$ \\
\hline $\begin{array}{l}\text { Koner et al., } \\
2004^{21}\end{array}$ & 29 & CABG & 6 & 5 & No & 10 & 5 & No & $\begin{array}{l}\text { Mortality, length of } \\
\text { hospital stay, } \mathrm{PaO}_{2} / \mathrm{FiO}_{2} \\
\text { ratio, } \mathrm{Paco}_{2} \text { level }\end{array}$ \\
\hline $\begin{array}{l}\text { Wrigge } \\
\text { et al., 200422 }\end{array}$ & 32 & $\begin{array}{l}\text { Thoracic } \\
\text { surgery }\end{array}$ & 6 & 10 & No & 12 & 0 & No & $\begin{array}{l}\mathrm{PaO}_{2} / \mathrm{FiO}_{2} \text { ratio, } \mathrm{PaCO}_{2} \\
\text { level }\end{array}$ \\
\hline $\begin{array}{l}\text { Wrigge } \\
\text { et al., } 2005^{23}\end{array}$ & 44 & Cardiac surgery & 6 & $\begin{array}{l}\text { Adjusted by } \\
\text { ARDSnet scale }\end{array}$ & No & 12 & $\begin{array}{l}\text { Adjusted by } \\
\text { ARDSnet scale }\end{array}$ & No & $\begin{array}{l}\text { Length of ICU stay, } \\
\mathrm{PaO}_{2} / \mathrm{FiO}_{2} \text { ratio, } \mathrm{PaCO}_{2} \\
\text { level }\end{array}$ \\
\hline $\begin{array}{l}\text { Zupancich } \\
\text { et al., } 2005^{24}\end{array}$ & 40 & CABG & 8 & 10 & No & $10-12$ & $2-3$ & No & $\begin{array}{l}\text { Mortality, } \mathrm{PaO}_{2} / \mathrm{FiO}_{2} \\
\text { ratio, } \mathrm{PaCO}_{2} \text { level }\end{array}$ \\
\hline $\begin{array}{l}\text { Michelet } \\
\text { et al., } 2006^{25}\end{array}$ & 52 & Esophagectomy & 5 & 5 & No & 9 & 0 & No & $\begin{array}{l}\text { Lung injury, pulmonary } \\
\text { infection, mortality, } \\
\mathrm{PaCO}_{2} \text { level }\end{array}$ \\
\hline $\begin{array}{l}\text { Cai et al., } \\
2007^{26}\end{array}$ & 16 & Neurosurgery & 6 & NR & $\mathrm{N}: \mathrm{O}$ & 10 & NR & No & $\begin{array}{l}\text { Atelectasis, } \mathrm{PaO}_{2} / \mathrm{FiO}_{2} \\
\text { ratio, } \mathrm{PaCO}_{2} \text { level }\end{array}$ \\
\hline $\begin{array}{l}\text { Determann } \\
\text { et al., } 2008^{27}\end{array}$ & 40 & $\begin{array}{l}\text { Abdominal } \\
\text { surgery }\end{array}$ & 6 & 10 & No & 12 & 0 & No & $\mathrm{PaCO}_{2}$ level \\
\hline $\begin{array}{l}\text { Lin et al., } \\
2008^{28}\end{array}$ & 40 & Esophagectomy & $5-6$ & $3-5$ & No & 10 & 0 & No & Atelectasis \\
\hline $\begin{array}{l}\text { Weingarten } \\
\text { et al., } 2010^{29}\end{array}$ & 40 & $\begin{array}{l}\text { Abdominal } \\
\text { surgery }\end{array}$ & 6 & 12 & Yes & 10 & 0 & No & $\begin{array}{l}\text { Lung injury, pulmonary } \\
\text { infection, atelectasis, } \\
\text { mortality, } \mathrm{PaO}_{2} / \mathrm{FiO}_{2} \\
\text { ratio, } \mathrm{PaCO}_{2} \text { level }\end{array}$ \\
\hline $\begin{array}{l}\text { Sundar } \\
\text { et al., } 2011^{30}\end{array}$ & 149 & Cardiac surgery & 6 & $\begin{array}{l}\text { Adjusted by } \\
\text { ARDSnet scale }\end{array}$ & No & 10 & $\begin{array}{l}\text { Adjusted by } \\
\text { ARDSnet scale }\end{array}$ & No & $\begin{array}{l}\text { Mortality, } \mathrm{PaO}_{2} / \mathrm{FiO}_{2} \\
\text { ratio }\end{array}$ \\
\hline $\begin{array}{l}\text { Yang et al., } \\
2011^{31}\end{array}$ & 100 & Lobectomy & 6 & 5 & No & 10 & 0 & No & $\begin{array}{l}\text { Lung injury, pulmonary } \\
\text { infection, atelectasis, } \\
\text { mortality, length of } \\
\text { hospital stay, length of } \\
\text { ICU stay, } \mathrm{PaCO}_{2} \text { level }\end{array}$ \\
\hline $\begin{array}{l}\text { Memtsoudis } \\
\text { et al., } 2012^{32}\end{array}$ & 26 & Spinal surgery & 6 & 8 & No & 12 & 0 & No & $\begin{array}{l}\mathrm{PaO}_{2} / \mathrm{FiO}_{2} \text { ratio, } \mathrm{PaCO}_{2} \\
\text { level }\end{array}$ \\
\hline $\begin{array}{l}\text { Treschan } \\
\text { et al., } 2012^{33}\end{array}$ & 101 & $\begin{array}{l}\text { Abdominal } \\
\text { surgery }\end{array}$ & 6 & 5 & Yes & 12 & 5 & Yes & $\begin{array}{l}\text { Lung injury, pulmonary } \\
\text { infection, mortality, } \\
\text { length of hospital stay, } \\
\text { length of ICU stay }\end{array}$ \\
\hline $\begin{array}{l}\text { Futier et al., } \\
2013^{34}\end{array}$ & 400 & $\begin{array}{l}\text { Abdominal } \\
\text { surgery }\end{array}$ & $6-8$ & $6-8$ & Yes & $10-12$ & 0 & No & $\begin{array}{l}\text { Lung injury, pulmonary } \\
\text { infection, atelectasis, } \\
\text { mortality, length of } \\
\text { hospital stay, length of } \\
\text { ICU stay, } \mathrm{PaCO}_{2} \text { level }\end{array}$ \\
\hline $\begin{array}{l}\text { Maslow } \\
\text { et al., } 2013^{35}\end{array}$ & 32 & Thoracotomy & 5 & 5 & No & 10 & 0 & No & $\begin{array}{l}\text { Lung injury, mortality, } \\
\text { length of hospital stay, } \\
\mathrm{PaO}_{2} / \mathrm{FiO}_{2} \text { ratio, } \mathrm{PaCO}_{2} \\
\text { level }\end{array}$ \\
\hline $\begin{array}{l}\text { Severgnini } \\
\text { et al., } 2013^{36}\end{array}$ & 55 & $\begin{array}{l}\text { Abdominal } \\
\text { surgery }\end{array}$ & 7 & 10 & Yes & 9 & 0 & No & Atelectasis, mortality \\
\hline $\begin{array}{l}\text { Shen et al., } \\
2013^{37}\end{array}$ & 101 & Esophagectomy & 5 & 5 & No & 8 & 0 & No & $\begin{array}{l}\text { Lung injury, pulmonary } \\
\text { infection, mortality }\end{array}$ \\
\hline $\begin{array}{l}\text { Qutub et al., } \\
2014^{38}\end{array}$ & 26 & $\begin{array}{l}\text { Thoracoscopic } \\
\text { surgery }\end{array}$ & 6 & 5 & No & 8 & 5 & No & $\begin{array}{l}\text { Lung injury, pulmonary } \\
\text { infection, atelectasis, } \\
\text { mortality }\end{array}$ \\
\hline
\end{tabular}


dations Assessment, Development and Evaluation (GRADE) approach. ${ }^{18}$ A summary table was prepared using the GRADE profiler (GRADEpro, version 3.6).

\section{Data synthesis}

For dichotomous outcome data, we calculated relative risks (RRs) with $95 \%$ confidence intervals (CIs). For continuous outcome data, we calculated

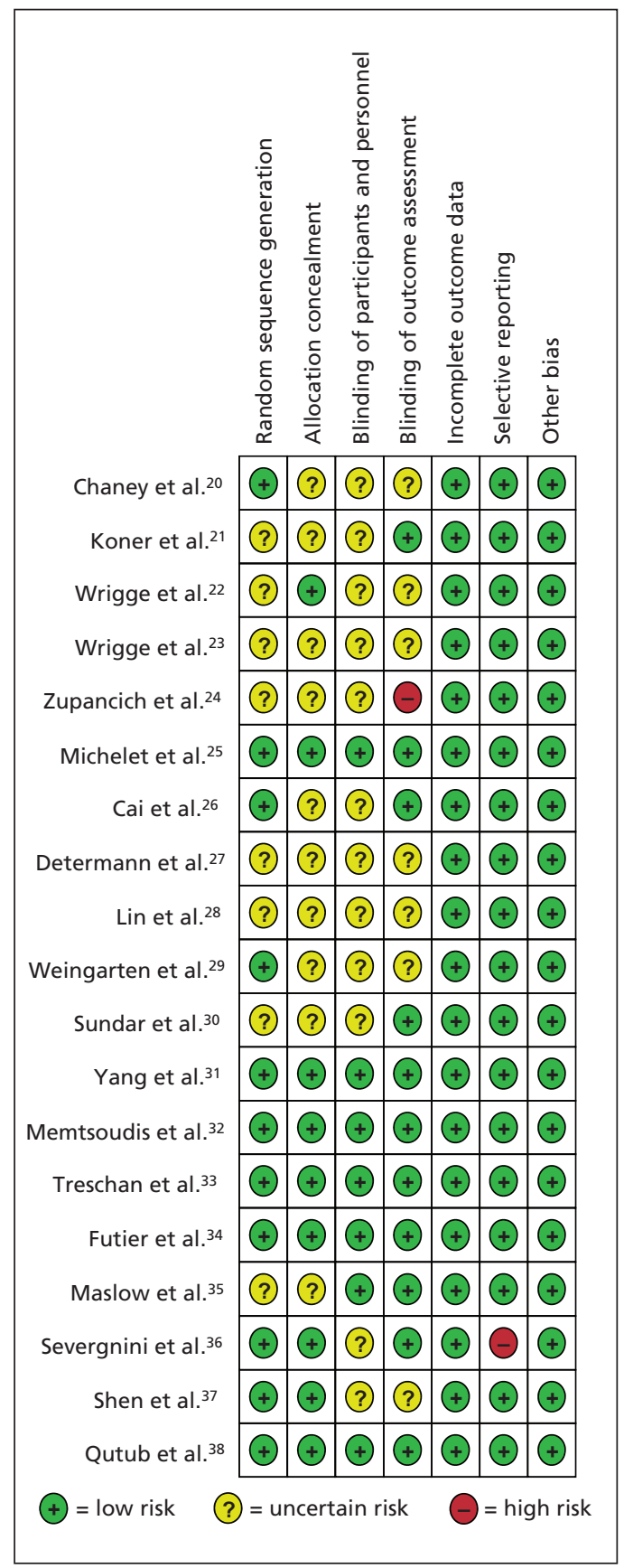

Figure 2: Appraisal of risk of bias of the included trials using the Cochrane risk-of-bias tool. ${ }^{17}$ Low risk = bias, if present, is unlikely to alter the results seriously, unclear risk = bias raises some doubt about the results, high risk = bias may alter the results seriously. standardized mean differences (SMDs) with 95\% CIs. We quantified heterogeneity using the $I^{2}$ statistic. We considered heterogeneity to be substantial if the $I^{2}$ value was greater than $50 \% .^{19}$

We pooled outcome data using randomeffects models regardless of heterogeneity. We also conducted subgroup analyses for dichotomous outcomes according to risk of bias (low v. unclear or high risk), surgical setting (cardiothoracic v. abdominal surgery) and tidal volume gradient $(5-6 \mathrm{~mL} / \mathrm{kg}$ v. $7-8 \mathrm{~mL} / \mathrm{kg})$. We considered a $p$ value of less than 0.05 to be statistically significant, except where otherwise specified. All statistical analyses were performed using Review Manager software (RevMan version 5.2; Nordic Cochrane Centre, Cochrane Collaboration).

\section{Results}

\section{Search results and study characteristics}

After review of the titles and abstracts of the 764 potentially eligible records identified through the literature search, we excluded 136 records because they were duplicates and a further 596 for other reasons (Figure 1). After review of the remaining 32 articles in full, $19 \mathrm{RCTs}^{20-38}$ met all of the inclusion criteria and were included in the meta-analysis. The Cohen kappa values for investigator agreement on study selection and inclusion were 0.90 and 0.82 , respectively.

The main characteristics of the included RCTs are summarized in Table 1. Demographic characteristics of the patients and ventilatory settings are summarized in Appendix 2 (available at www .cmaj.ca/lookup/suppl/doi:10.1503/cmaj.141005//DC1). The trials were published between 2000 and 2014. The sample size ranged from 16 to 400 (total 1348). Patients underwent a variety of surgical procedures: cardiothoracic surgery in 12 trials, abdominal surgery in 5 trials and other types of surgery in 2 trials. In the intervention groups, the tidal volumes ranged from 5 to $8 \mathrm{~mL} / \mathrm{kg}$. In the conventional ventilation groups, the tidal volumes ranged from 8 to $12 \mathrm{~mL} / \mathrm{kg}$. Of the 2 primary outcomes, lung injury was reported in 8 of the 19 trials and pulmonary infection in 7 trials. Of the secondary outcomes, atelectasis was reported as an outcome in 7 trials, mortality in 13 trials, length of hospital stay in 6, length of ICU stay in 4, $\mathrm{PaO}_{2} / \mathrm{FiO}_{2}$ ratio in 9 and $\mathrm{PaCO}_{2}$ levels in 13 trials.

The details of the risk-of-bias assessment are summarized in Figure 2. Six trials were judged to be at low risk of bias, 11 at unclear risk and 2 at high risk of bias. Eleven trials generated an adequate randomization sequence, and 9 trials reported appropriate allocation concealment. The GRADE evidence profiles for the primary and 
secondary outcomes are shown in Appendix 3 (available at www.cmaj.ca/lookup/suppl/doi :10.1503/cmaj.141005/-/DC1). The GRADE level of evidence was low for atelectasis, length of ICU stay, $\mathrm{PaO}_{2} / \mathrm{FiO}_{2}$ ratio and $\mathrm{PaCO}_{2}$ levels; moderate for lung injury and length of hospital stay; and high for pulmonary infection and mortality.

\section{Effect on outcomes}

Compared with patients who received conventional ventilation, those who received lungprotective ventilation had a decreased risk of lung injury (RR $0.36,95 \%$ CI 0.17 to $0.78 ; P^{2}=$ $0 \%$ ) and pulmonary infection (RR $0.46,95 \%$ CI 0.26 to $0.83 ; r^{2}=8 \%$ ) (Figure 3 ). For the secondary outcomes, no significant differences were observed between the 2 groups in atelectasis, mortality, length of hospital stay, length of ICU stay or $\mathrm{PaO}_{2} / \mathrm{FiO}_{2}$ ratio (Figures 4,5 and 6). Patients who received lung-protective ventilation had significantly higher $\mathrm{PaCO}_{2}$ levels than those who received conventional ventilation (SMD $0.47,95 \%$ CI 0.18 to $0.75 ; r^{2}=65 \%$ ) (Figure 6 ).

The findings of the subgroup analyses for the dichotomous outcomes according to methodology and clinical features are summarized in
Appendix 4 (available at www.cmaj.ca/lookup /suppl/doi:10.1503/cmaj.141005/-/DC1). For lung injury, pulmonary infection and atelectasis, we found significant differences in the results in various subgroup analyses. For mortality, the results did not change significantly.

\section{Interpretation}

In our meta-analysis of 19 RCTs, anesthetized patients who received ventilation with lower tidal volumes during surgery had a lower risk of lung injury and pulmonary infection and higher $\mathrm{PaCO}_{2}$ levels than those who received conventional ventilation with higher tidal volumes. Use of a lung-protective ventilation strategy with lower tidal volumes of $5-8 \mathrm{~mL} / \mathrm{kg}$ may reduce the risk of lung injury and pulmonary infection among patients undergoing surgery.

In a previous meta-analysis of 20 studies comparing lower and higher tidal volumes for mechanical ventilation in patients without acute respiratory distress syndrome, Serpa Neto and colleagues $^{13}$ found that use of lower tidal volumes was associated with a decrease in lung injury, pulmonary infection, atelectasis and

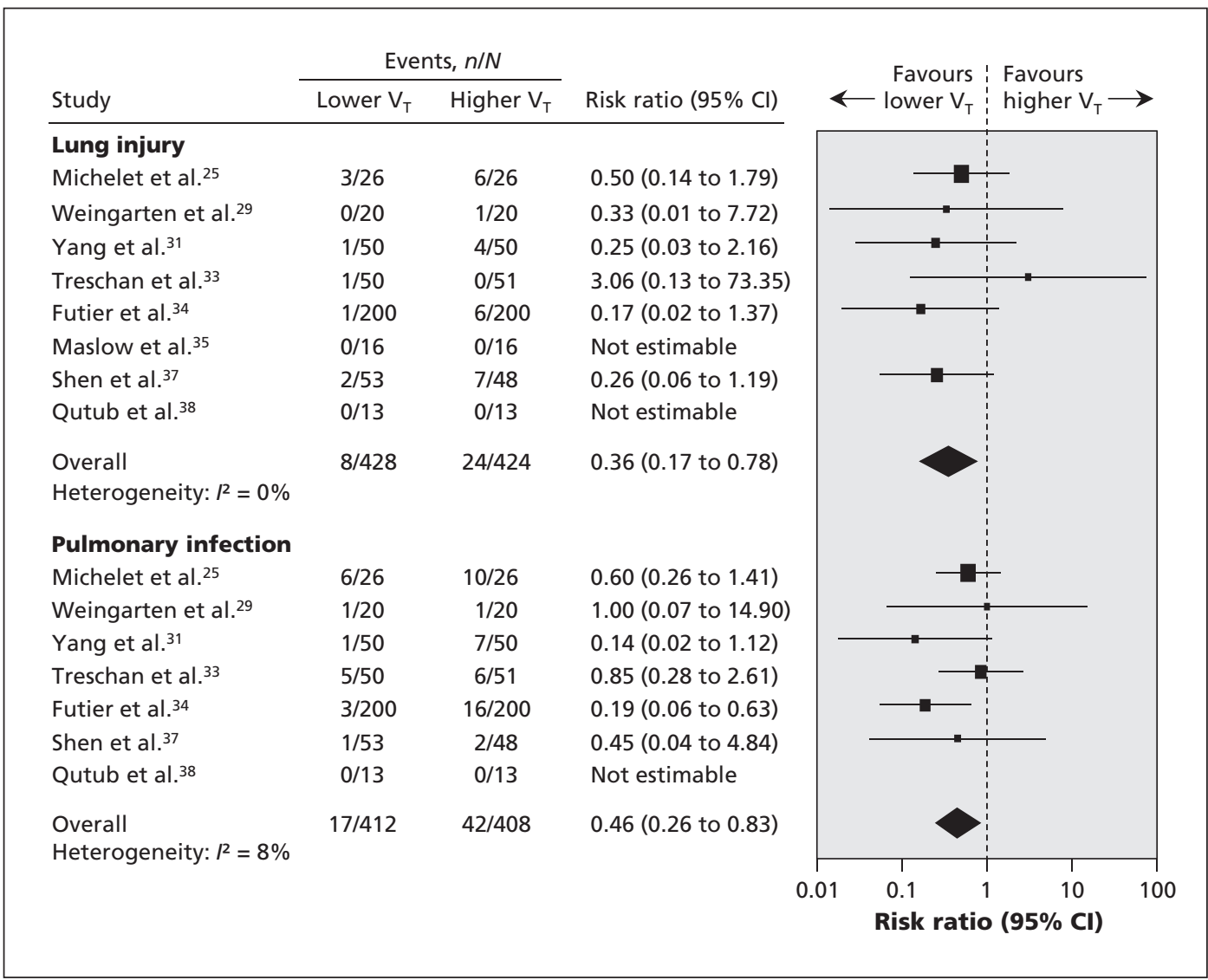

Figure 3: Effect of lung-protective ventilation with lower tidal volumes on lung injury and pulmonary infection among patients undergoing surgery. A risk ratio less than $\mathbf{1 . 0}$ indicates an effect in favour of lung-protective ventilation. $\mathrm{Cl}=$ confidence interval, $\mathrm{V}_{\mathrm{T}}=$ tidal volume. 
mortality. However, 5 observational studies ${ }^{39-43}$ accounted for $82.1 \%, 55.8 \%, 83.1 \%$ and $76.4 \%$ of the total weight in the primary analysis of lung injury, pulmonary infection, atelectasis and mortality prevention, respectively, which may compromise the reliability of the results. Furthermore, the authors included critically ill patients in the ICU as well as surgical patients. Therefore, their results may not be considered as definitive.

To specify better the effect of protective ventilation in surgical patients, Hemmes and colleagues ${ }^{14}$ excluded critically ill patients in the ICU from their meta-analysis and focused on postoperative pulmonary complications in 8 trials. They found that protective ventilation was associated with a decrease in lung injury, pulmonary infection and atelectasis. However, 2 observational studies ${ }^{42,43}$ accounted for $69.4 \%$,
$57.2 \%$ and $76.2 \%$ of the total weight in the primary analysis of lung injury, pulmonary infection and atelectasis prevention, respectively, which may compromise the reliability of the results. Furthermore, the authors did not consider gas exchange variables (e.g., $\mathrm{PaO}_{2} / \mathrm{FiO}_{2}$ ratio and $\mathrm{PaCO}_{2}$ levels) as outcomes, which are useful for clinicians. As a result, their findings did not settle the debate over the use of lungprotective ventilation in patients undergoing surgery.

Differences between our meta-analysis and the previous ones should be noted. In the 2 previous meta-analyses, most of the data came from observational studies, which are subject to bias, and the interpretation of their findings is not straightforward. In addition, the data from RCTs and observational studies were pooled together. To provide more credible evidence and

\begin{tabular}{|c|c|c|c|c|c|}
\hline \multirow[b]{2}{*}{ Study } & \multicolumn{2}{|c|}{ Events, $n / N$} & \multirow[b]{2}{*}{ Risk ratio $(95 \% \mathrm{Cl})$} & \multirow{2}{*}{$\begin{array}{r}\text { Favours } \\
\leftarrow \text { lower } \mathrm{V}_{\mathrm{T}}\end{array}$} & \multirow{2}{*}{$\begin{array}{l}\text { Favours } \\
\text { higher } \mathrm{V}_{\mathrm{T}} \longrightarrow\end{array}$} \\
\hline & Lower $\mathrm{V}_{\mathrm{T}}$ & Higher $\mathrm{V}_{\mathrm{T}}$ & & & \\
\hline \multicolumn{6}{|l|}{ Atelectasis } \\
\hline Cai et al. ${ }^{26}$ & $7 / 8$ & $5 / 8$ & 1.40 (0.77 to 2.54$)$ & & \\
\hline Lin et al. ${ }^{28}$ & $3 / 20$ & $2 / 20$ & $1.50(0.28$ to 8.04$)$ & & \\
\hline Weingarten et al. ${ }^{29}$ & $4 / 20$ & $5 / 20$ & $0.80(0.25$ to 2.55$)$ & & \\
\hline Yang et al. ${ }^{31}$ & $1 / 50$ & $3 / 50$ & 0.33 (0.04 to 3.10$)$ & & \\
\hline Futier et al. ${ }^{34}$ & $13 / 200$ & $34 / 200$ & $0.38(0.21$ to 0.70$)$ & & \\
\hline Severgnini et al. ${ }^{36}$ & $2 / 28$ & $7 / 27$ & 0.28 (0.06 to 1.21$)$ & & \\
\hline Qutub et al. ${ }^{38}$ & $1 / 13$ & $0 / 13$ & 3.00 (0.13 to 67.51$)$ & & \\
\hline $\begin{array}{l}\text { Overall } \\
\text { Heterogeneity: } I^{2}=59 \%\end{array}$ & $31 / 339$ & $56 / 338$ & 0.71 (0.35 to 1.43$)$ & & \\
\hline \multicolumn{6}{|l|}{ Mortality } \\
\hline Chaney et al. ${ }^{20}$ & $0 / 12$ & $1 / 13$ & $0.36(0.02$ to 8.05$)$ & & \\
\hline Koner et al. ${ }^{21}$ & $0 / 15$ & $0 / 14$ & Not estimable & & \\
\hline Zupancich et al. ${ }^{24}$ & $0 / 20$ & $0 / 20$ & Not estimable & & \\
\hline Michelet et al. ${ }^{25}$ & $2 / 26$ & $1 / 26$ & 2.00 (0.19 to 20.72$)$ & & \\
\hline Weingarten et al. ${ }^{29}$ & $1 / 20$ & $1 / 20$ & $1.00(0.07$ to 14.90$)$ & & \\
\hline Sundar et al. ${ }^{30}$ & $1 / 75$ & $2 / 74$ & 0.49 (0.05 to 5.32$)$ & & \\
\hline Yang et al. ${ }^{31}$ & $0 / 50$ & $1 / 50$ & 0.33 (0.01 to 7.99$)$ & & \\
\hline Treschan et al. ${ }^{33}$ & $3 / 50$ & $5 / 51$ & 0.61 (0.15 to 2.43 ) & & \\
\hline Futier et al. ${ }^{34}$ & $6 / 200$ & $7 / 200$ & 0.86 (0.29 to 2.51$)$ & & \\
\hline Maslow et al..$^{35}$ & $0 / 16$ & $0 / 16$ & Not estimable & & \\
\hline Severgnini et al. ${ }^{36}$ & $0 / 28$ & $0 / 27$ & Not estimable & & \\
\hline Shen et al. ${ }^{37}$ & $0 / 53$ & $0 / 48$ & Not estimable & & \\
\hline Qutub et al. ${ }^{38}$ & $0 / 13$ & $0 / 13$ & Not estimable & & \\
\hline \multirow{3}{*}{$\begin{array}{l}\text { Overall } \\
\text { Heterogeneity: } I^{2}=0 \%\end{array}$} & $13 / 578$ & $18 / 572$ & 0.75 (0.38 to 1.49$)$ & & \\
\hline & & & & \multirow{2}{*}{\multicolumn{2}{|c|}{$\begin{array}{cccc}0.01 & 0.1 & 1 & 10 \\
& \text { Risk ratio } & (95 \% \mathrm{Cl})\end{array}$}} \\
\hline & & & & & \\
\hline
\end{tabular}

Figure 4: Effect of lung-protective ventilation with lower tidal volumes on atelectasis and mortality among patients undergoing surgery. A risk ratio less than 1.0 indicates an effect in favour of lung-protective ventilation. $\mathrm{Cl}=$ confidence interval, $\mathrm{V}_{\mathrm{T}}=$ tidal volume. 
minimize potential bias, we included only RCTs and focused on a specific patient population, namely anesthetized adults undergoing surgery who did not have acute respiratory distress syndrome at the onset of mechanical ventilation. Our meta-analysis of 19 RCTs involving 1383 patients suggests that patients who receive lungprotective ventilation with lower tidal volumes are at decreased risk of lung injury and pulmonary infection and have higher $\mathrm{PaCO}_{2}$ levels after surgery. We found no significant differences between the intervention and control groups in atelectasis, mortality, length of hospital or ICU stay, and $\mathrm{PaO}_{2} / \mathrm{FiO}_{2}$ ratio.

\section{Limitations}

Our study has limitations. First, for each of the dichotomous outcomes, the number of events was smaller than the optimal information size required. This means that our effect estimates may be inflated, which limits the strength of the inferences that can be drawn. ${ }^{44}$

Second, in some of the trials, the intervention group received lower tidal volumes and higher positive end-expiratory pressure, whereas the control group received higher tidal volumes and lower positive end-expiratory pressure. It is difficult to know whether the beneficial effect was from the lower tidal volumes, the higher positive end-expiratory pressure, or both. However, a recent international, multicentre RCT by the European Society of Anaesthesiology (the PROVHILO trial) involving patients undergoing open abdominal surgery who received ventilation with low tidal volumes reported no difference in clinical outcomes between patients given higher and those given lower positive endexpiratory pressure. ${ }^{45}$ This finding suggests that positive end-expiratory pressure is not as important a determinant of postoperative pulmonary outcomes as tidal volume is.

\section{Conclusion}

In anesthetized adults undergoing surgery, lungprotective ventilation with tidal volumes of 5-8 $\mathrm{mL} / \mathrm{kg}$ was associated with a decreased incidence of lung injury and pulmonary infection and higher $\mathrm{PaCO}_{2}$ levels. Implementation of a lung-protective ventilation strategy with lower tidal volumes may lower the risk of lung injury and pulmonary infection. However, our results should be interpreted with caution, because data were limited by insufficient information size. Larger RCTs addressing this question are needed to provide data better applicable to clinical practice.

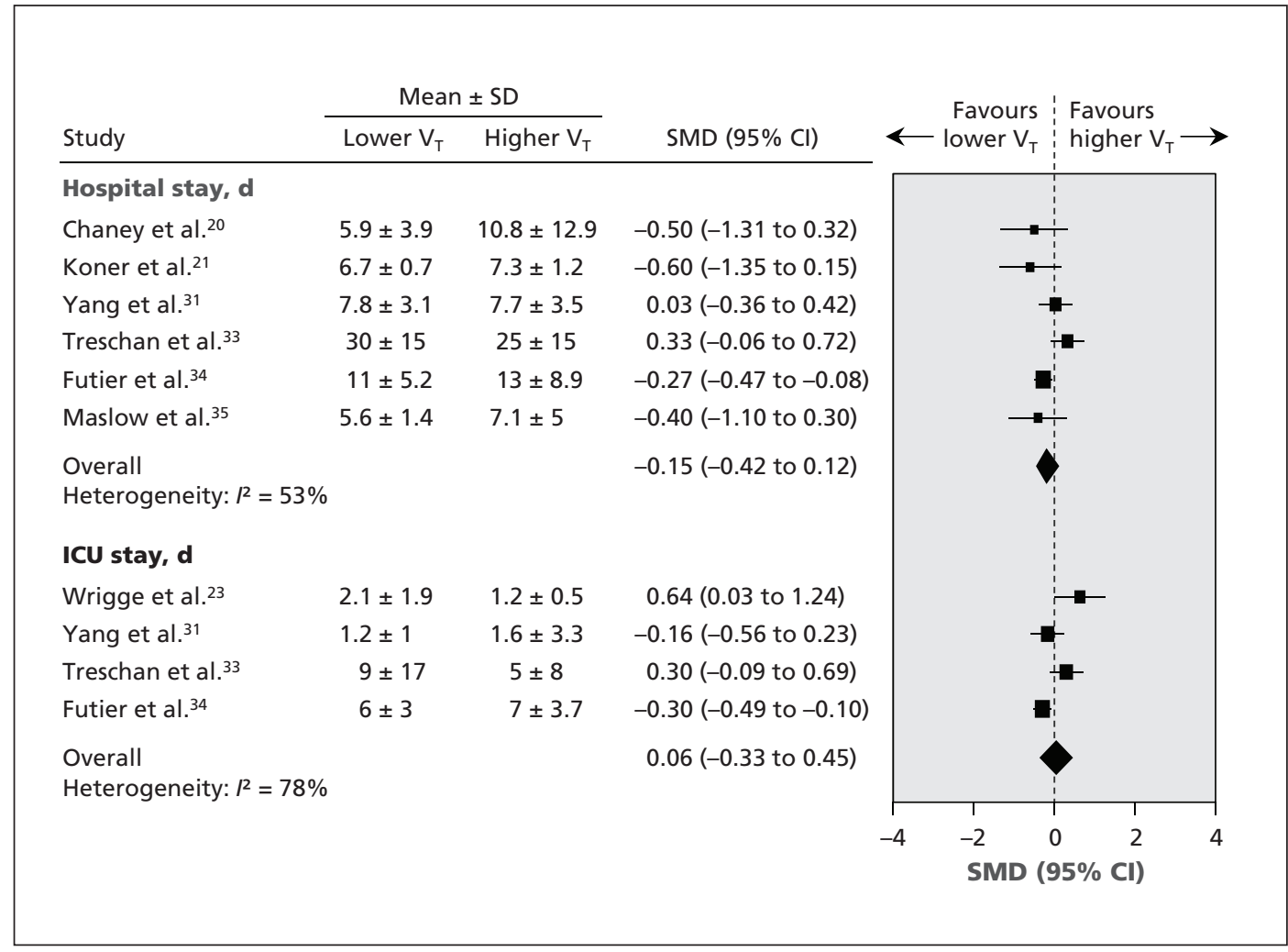

Figure 5: Effect of lung-protective ventilation with lower tidal volumes on length of stay in hospital and in intensive care unit (ICU) among patients undergoing surgery. A standardized mean difference (SMD) less than zero indicates an effect in favour of lung-protective ventilation. $\mathrm{Cl}=$ confidence interval, $\mathrm{V}_{\mathrm{T}}=$ tidal volume. 


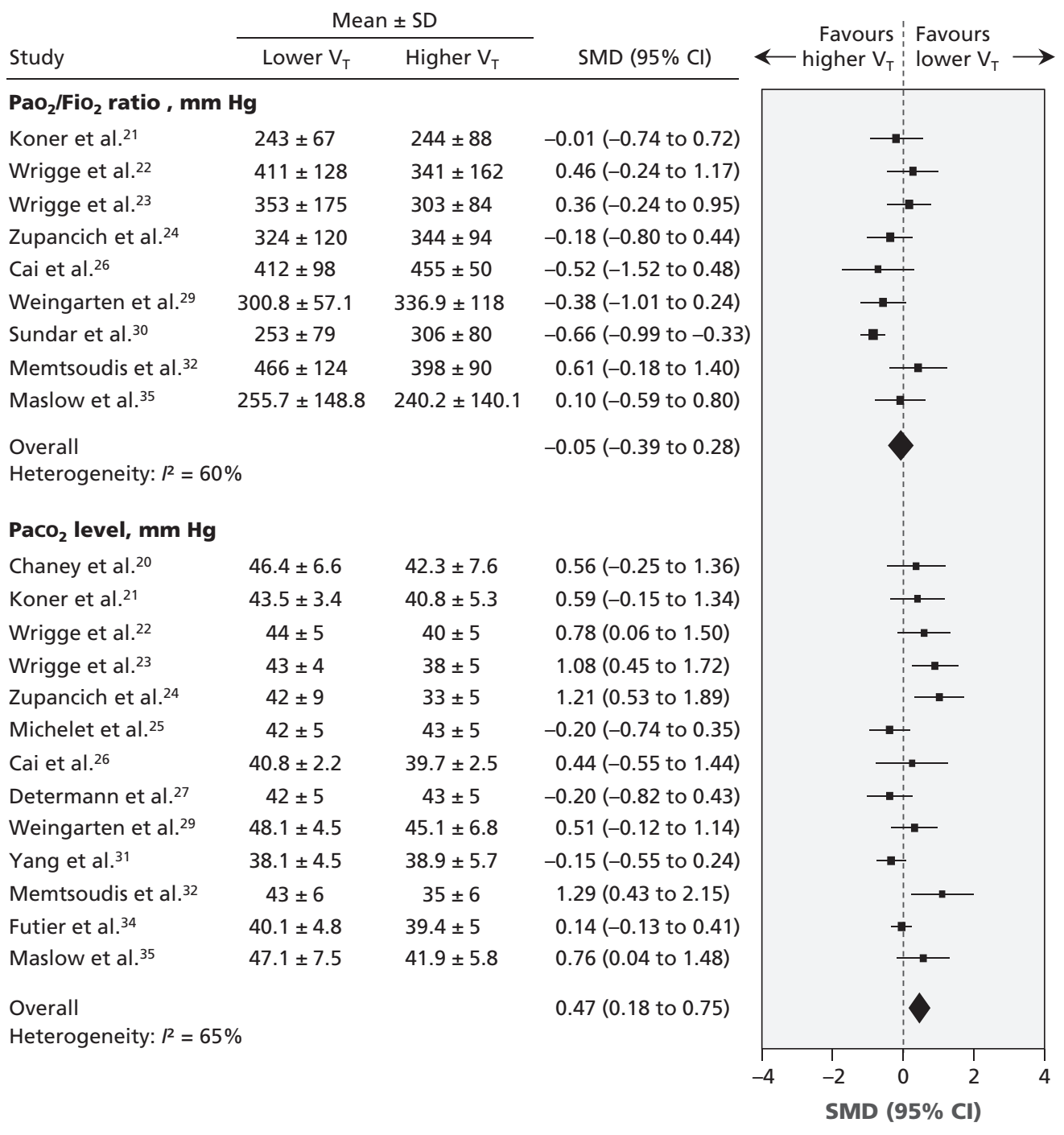

Figure 6: Effect of lung-protective ventilation with lower tidal volumes on the $\mathrm{PaO}_{2} / \mathrm{FiO}_{2}$ ratio (normal 400 $500 \mathrm{~mm} \mathrm{Hg}$ ) and the $\mathrm{PaCO}_{2}$ level (normal 35-45 mm Hg) among patients undergoing surgery. A standardized mean difference (SMD) greater than zero indicates an effect in favour of lung-protective ventilation. $\mathrm{Cl}=$ confidence interval, $\mathrm{FiO}_{2}=$ fraction of inspired oxygen, $\mathrm{PaCO}_{2}=$ arterial partial pressure of carbon dioxide, $\mathrm{PaO}_{2}=$ arterial partial pressure of oxygen, $\mathrm{V}_{\mathrm{T}}=$ tidal volume.

\section{References}

1. Weiser TG, Regenbogen SE, Thompson KD, et al. An estimation of the global volume of surgery: a modelling strategy based on available data. Lancet 2008;372:139-44.

2. Rock P, Rich PB. Postoperative pulmonary complications. Curr Opin Anaesthesiol 2003;16:123-31.

3. Smetana GW, Lawrence VA, Cornell JE; American College of Physicians. Preoperative pulmonary risk stratification for noncardiothoracic surgery: systematic review for the American College of Physicians. Ann Intern Med 2006;144:581-95.

4. Johnson RG, Arozullah AM, Neumayer L, et al. Multivariable predictors of postoperative respiratory failure after general and vascular surgery: results from the Patient Safety in Surgery Study. J Am Coll Surg 2007;204:1188-98.

5. Finks JF, Osborne NH, Birkmeyer JD. Trends in hospital volume and operative mortality for high-risk surgery. N Engl J Med 2011; 364:2128-37.

6. Bendixen HH, Hedley-Whyte J, Laver MB. Impaired oxygenation in surgical patients during general anesthesia with controlled ventilation: a concept of atelectasis. N Engl J Med 1963 269:991-6.
7. Slutsky AS. Lung injury caused by mechanical ventilation. Chest 1999;116:9S-15S

8. Dreyfuss D, Saumon G. Ventilator-induced lung injury: lessons from experimental studies. Am J Respir Crit Care Med 1998; 157:294-323.

9. Gajic O, Frutos-Vivar F, Esteban A, et al. Ventilator settings as a risk factor for acute respiratory distress syndrome in mechanically ventilated patients. Intensive Care Med 2005;31:922-6.

10. Carney D, DiRocco J, Nieman G. Dynamic alveolar mechanics and ventilator-induced lung injury. Crit Care Med 2005;33: S122-8.

11. Amato MB, Barbas CS, Medeiros DM, et al. Effect of a protective-ventilation strategy on mortality in the acute respiratory distress syndrome. N Engl J Med 1998;338:347-54.

12. Acute Respiratory Distress Syndrome Network. Ventilation with lower tidal volumes as compared with traditional tidal volumes for acute lung injury and the acute respiratory distress syndrome. N Engl J Med 2000;342:1301-8.

13. Serpa Neto A, Cardoso SO, Manetta JA, et al. Association between use of lung-protective ventilation with lower tidal volumes and clinical outcomes among patients without acute respiratory distress syndrome: a meta-analysis. JAMA 2012;308:1651-9. 
14. Hemmes SN, Serpa Neto A, Schultz MJ. Intraoperative ventilatory strategies to prevent postoperative pulmonary complications: a meta-analysis. Curr Opin Anaesthesiol 2013;26:126-33.

15. Higgins JPT, Green S, editors. Cochrane handbook for systematic reviews of interventions version 5.1.0 [updated March 2011]. Oxford (UK): The Cochrane Collaboration; 2011. Available: www.cochrane.org/handbook (accessed 2014 Nov. 25).

16. Moher D, Liberati A, Tetzlaff J, et al.; PRISMA Group. Preferred reporting items for systematic reviews and meta-analyses: the PRISMA statement. BMJ 2009;339:b2535.

17. Higgins JP, Altman DG, Gøtzsche PC, et al. The Cochrane Collaboration's tool for assessing risk of bias in randomised trials. BMJ 2011;343:d5928.

18. Guyatt GH, Oxman AD, Vist GE, et al.; GRADE Working Group. GRADE: an emerging consensus on rating quality of evidence and strength of recommendations. BMJ 2008;336:924-6.

19. Higgins JP, Thompson SG, Deeks JJ, et al. Measuring inconsistency in meta-analyses. BMJ 2003;327:557-60.

20. Chaney MA, Nikolov MP, Blakeman BP, et al. Protective ventilation attenuates postoperative pulmonary dysfunction in patients undergoing cardiopulmonary bypass. J Cardiothorac Vasc Anesth 2000; $14: 514-8$

21. Koner O, Celebi S, Balci H, et al. Effects of protective and conventional mechanical ventilation on pulmonary function and systemic cytokine release after cardiopulmonary bypass. Intensive Care Med 2004;30:620-6.

22. Wrigge H, Uhlig U, Zinserling J, et al. The effects of different ventilatory settings on pulmonary and systemic inflammatory responses during major surgery. Anesth Analg 2004;98:775-81.

23. Wrigge $H$, Uhlig $U$, Baumgarten $G$, et al. Mechanical ventilation strategies and inflammatory responses to cardiac surgery: a prospective randomized clinical trial. Intensive Care Med 2005;31: 1379-87.

24. Zupancich E, Paparella D, Turani F, et al. Mechanical ventilation affects inflammatory mediators in patients undergoing cardiopulmonary bypass for cardiac surgery: a randomized clinical trial. J Thorac Cardiovasc Surg 2005;130:378-83.

25. Michelet P, D'Journo XB, Roch A, et al. Protective ventilation influences systemic inflammation after esophagectomy: a randomized controlled study. Anesthesiology 2006;105:911-9.

26. Cai H, Gong H, Zhang L, et al. Effect of low tidal volume ventilation on atelectasis in patients during general anesthesia: a computed tomographic scan. J Clin Anesth 2007;19:125-9.

27. Determann RM, Wolthuis EK, Choi G, et al. Lung epithelial injury markers are not influenced by use of lower tidal volumes during elective surgery in patients without preexisting lung injury. Am J Physiol Lung Cell Mol Physiol 2008;294:L344-50.

28. Lin WQ, Lu XY, Cao LH, et al. Effects of the lung protective ventilatory strategy on proinflammatory cytokine release during one-lung ventilation. Ai Zheng 2008;27:870-3.

29. Weingarten TN, Whalen FX, Warner DO, et al. Comparison of two ventilatory strategies in elderly patients undergoing major abdominal surgery. Br J Anaesth 2010;104:16-22.

30. Sundar S, Novack V, Jervis K, et al. Influence of low tidal volume ventilation on time to extubation in cardiac surgical patients. Anesthesiology 2011;114:1102-10.

31. Yang M, Ahn HJ, Kim K, et al. Does a protective ventilation strategy reduce the risk of pulmonary complications after lung cancer surgery? A randomized controlled trial. Chest 2011;139: $530-7$

32. Memtsoudis SG, Bombardieri AM, Ma Y, et al. The effect of low versus high tidal volume ventilation on inflammatory markers in healthy individuals undergoing posterior spine fusion in the prone position: a randomized controlled trial. J Clin Anesth 2012;24:263-9.
33. Treschan TA, Kaisers W, Schaefer MS, et al. Ventilation with low tidal volumes during upper abdominal surgery does not improve postoperative lung function. Br J Anaesth 2012;109: 263-71.

34. Futier E, Constantin JM, Paugam-Burtz C, et al.; IMPROVE Study Group. A trial of intraoperative low-tidal-volume ventilation in abdominal surgery. N Engl J Med 2013;369:428-37.

35. Maslow AD, Stafford TS, Davignon KR, et al. A randomized comparison of different ventilator strategies during thoracotomy for pulmonary resection. J Thorac Cardiovasc Surg 2013;146:38-44.

36. Severgnini P, Selmo G, Lanza C, et al. Protective mechanical ventilation during general anesthesia for open abdominal surgery improves postoperative pulmonary function. Anesthesiology 2013;118:1307-21

37. Shen $\mathrm{Y}$, Zhong $\mathrm{M}, \mathrm{Wu} \mathrm{W}$, et al. The impact of tidal volume on pulmonary complications following minimally invasive esophagectomy: a randomized and controlled study. J Thorac Cardiovasc Surg 2013;146:1267-73.

38. Qutub H, El-Tahan MR, Mowafi HA. etal. Effect of tidal volume on extravascular lung water content during one-lung ventilation for video-assisted thoracoscopic surgery: a randomised, controlled trial. Eur J Anaesthesiol 2014;31:466-73.

39. Gajic O, Dara SI, Mendez JL, et al. Ventilator-associated lung injury in patients without acute lung injury at the onset of mechanical ventilation. Crit Care Med 2004;32:1817-24.

40. Wolthuis EK, Veelo DP, Choi G, et al. Mechanical ventilation with lower tidal volumes does not influence the prescription of opioids or sedatives. Crit Care 2007;11:R77-85.

41. Yilmaz M, Keegan MT, Iscimen R, et al. Toward the prevention of acute lung injury: protocol-guided limitation of large tidal volume ventilation and inappropriate transfusion. Crit Care Med 2007;35:1660-6

42. Licker M, Diaper J, Villiger Y, et al. Impact of intraoperative lung-protective interventions in patients undergoing lung cancer surgery. Crit Care 2009;13:R41-50.

43. Fernandez-Bustamante A, Wood CL, Tran ZV, et al. Intraoperative ventilation: incidence and risk factors for receiving large tidal volumes during general anesthesia. BMC Anesthesiol 2011;11:22-9.

44. Thorlund $\mathrm{K}$, Imberger G, Walsh $\mathrm{M}$, et al. The number of patients and events required to limit the risk of overestimation of intervention effects in meta-analysis - a simulation study. PLOS ONE 2011;6:e25491.

45. Hemmes SN, Gama de Abreu M, Pelosi P, et al.; PROVE Network Investigators for the Clinical Trial Network of the European Society of Anaesthesiology. High versus low positive end-expiratory pressure during general anaesthesia for open abdominal surgery (PROVHILO trial): a multicentre randomised controlled trial. Lancet 2014;384:495-503.

Affiliations: Department of Anesthesiology (Gu, Liu), First Affiliated Hospital of Guangxi Medical University, Nanning, China; Department of Anesthesiology (Wang), General Hospital of Jinan Military Command, Jinan, China.

Contributors: Wan-Jie Gu and Jing-Chen Liu contributed substantially to the concept and design of the study and to the acquisition, analysis and interpretation of data. Fei Wang contributed substantially to the interpretation of data. Wan-Jie Gu drafted the article, and Fei Wang and Jing-Chen Liu revised it critically for important intellectual content. All of the authors approved the final version of the manuscript submitted for publication and agreed to act as guarantors of the work.

Funding: No funding was received for this study. 